\title{
Profiles of faecal output of rare earth elements and stable isotopic tracers of iron and zinc after oral administration
}

\author{
Ulvi Ulusoy $^{1 *}$ and John E. Whitley ${ }^{2}$ \\ ${ }^{1}$ Cumhuriyet University, Department of Chemistry, 58140-Sivas, Turkey \\ ${ }^{2}$ Scottish Universities Research and Reactor Centre, Rankine Avenue, Scottish Enterprise Technology Park, East Kilbride \\ G75 OQF, UK
}

(Received 29 July 1998 - Revised 4 January 2000 - Accepted 6 March 2000)

\begin{abstract}
The objectives of this study were to confirm the non-absorbability and the reproducibility of faecal excretion kinetics of orally administered rare earth elements, and to investigate the excretion profiles of rare earth elements and stable isotopic tracers of $\mathrm{Fe}$ and $\mathrm{Zn}$ to establish the extent to which rare earth element markers duplicate the behaviour of isotopic tracers. Two investigations were performed: (1) six healthy subjects consumed a solution containing five rare earth elements in amounts varying from 1 to $10 \mathrm{mg}$; (2) seven healthy subjects were given a standard solution labelled with Sm marker and ${ }^{57} \mathrm{Fe}$ tracer, and a meal labelled with $\mathrm{Yb}$ marker and ${ }^{58} \mathrm{Fe}$ and ${ }^{70} \mathrm{Zn}$ tracers. Individual faecal samples were collected and analysed to determine recoveries of rare earth elements and unabsorbed isotopic tracers. The mean values for recoveries were 94.1 (SD 4.5) \% for the five rare earth elements, and 103 (SD 3.0) $\%$ and 99.8 (SD 2.8) \% for $\mathrm{Sm}$ and $\mathrm{Yb}$ respectively. For Fe consumed with the solution, excretion kinetics of the rare earth element marker and unabsorbed tracers with cumulative collections of the first two and three faecal samples were identical, but endogenous excretion of $\mathrm{Fe}$ was significant $(P<0.05)$ in stools collected after the third. For Fe and $\mathrm{Zn}$ consumed with the meal, the excretion kinetics for the first two individual faecal samples and composites of sequential outputs were identical. Rare earth elements can be used as markers in studies of measurement of absorption. The dose of tracer required for the measurement of absorption would be reduced proportionally to the reduction of the period of faecal sampling, so that studies with stable isotopes would be more economical, thus enabling epidemiological investigations.
\end{abstract}

\section{Rare earth element markers: Iron absorption: Zinc absorption: Stable isotopes}

\begin{abstract}
Measurement of the absorption of trace elements has often been determined by a chemical balance approach. The difference between the element content of intake and faecal output (disappearance) is considered to be the amount absorbed. This approach does not take account of the contribution of endogenously excreted elements to faecal losses, and requires reliable cooperation of subjects, usually involving confinement in a metabolic unit over an extended period of at least 1 week (O'Dell, 1984; Mertz, 1987).

The accuracy of the chemical balance approach can be improved by using radioactive or stable isotopic tracers. Use of radioactive tracers is limited due to risks associated with radiation exposure. Measurement of absorption of isotopic tracers requires collection of all output until excretion of unabsorbed tracer is completed, which takes 5-10 d (Solomons et al. 1982; Johnson et al. 1988). The
\end{abstract}

contribution of a re-excreted fraction of tracer, initially absorbed, to the faecal pool during this period can be significant (Charlton \& Bothwell, 1983; Fairweather-Tait et al. 1993), resulting in under-estimation of absorption. Incomplete collection can result in over-estimation of absorption. By the combined use of tracer and a suitable non-absorbable marker the disappearance (net intestinal uptake) can be determined with collection for a reduced period of time by taking account of recovery of the marker. Markers useful for such an approach should principally be non-absorbable and their faecal excretion kinetics should duplicate those of the unabsorbed fraction of the nutrient tested (Kotb \& Luckey, 1972). Polyethylene glycol and radio-opaque pellets are commonly used markers in measurements of absorption by the disappearance approach (Turnlund et al. 1991; Fairweather-Tait et al. 1992), but

\footnotetext{
Abbreviations: ICP, inductively-coupled plasma; NAA, neutron activation analysis; rare earths, rare earth elements.

* Corresponding author: Dr Ulvi Ulusoy, fax +90346 2191186, email ulusoy@cumhuriyet.edu.tr
} 
these markers are only suitable for ensuring quantitative faecal recovery of tracer (Morgan, 1986). $\mathrm{CrCl}_{3}$ and $\mathrm{BaSO}_{4}$ have been used as markers for measurement of $\mathrm{Fe}$ and $\mathrm{Zn}$ absorption with reduced faecal collection (Jasani \& Fletcher, 1972; Payton et al. 1982), but the markers and $\mathrm{Fe}$ or $\mathrm{Zn}$ were labelled with radioactive tracers.

The rare earth elements (rare earths) have been shown to be potential markers with features appropriate for an ideal marker. They have low natural abundance, low limits of determination, suitable physico-chemical characteristics, and are not absorbed by the gut (Venugopal \& Luckey, 1975). Low accumulation of rare earths in plants, due to their low solubility in natural water (Laul et al. 1988) is evidence of low intake. Investigations with laboratory animals have shown that no absorption occurs through the gastrointestinal tracts of adult vertebrates and there is no transfer of rare earths from mother to fetus (Hutcheson et al. 1975).

Investigations of faecal recoveries of orally administered rare earths (not radioactive) from human subjects were first described by Luckey et al. (1977) for five of the rare earths, where the recoveries were not quantitative and interelement variations of the recoveries were significant (cv 5$10 \%)$. Although the concentrations of rare earths in various human tissues have been determined (Pietra et al. 1985; Esposito et al. 1993), investigations of the inputs of rare earths to human subjects via food and drink are rare, since such evaluation is difficult due to the amounts of rare earths in dietary intakes being very low or highly variable.

The objectives of this present investigation are to confirm the non-absorbability (or high faecal recovery) of orally administered rare earths and the reproducibility of their excretion kinetics, and investigation of the excretion profiles of rare earths and tracers to establish the extent to which rare earth markers duplicate the behaviour of isotopic tracers. To accomplish this, two investigations were conducted. In the first, faecal recoveries of five selected rare earths consumed in various amounts as single doses were investigated with particular attention to their background levels in faecal samples provided before administration. In the second investigation, the excretion kinetics of rare earths and fractions of isotopic tracers not absorbed were compared, results being obtained from two different standard inputs, each labelled with a rare earth marker and isotopic tracer of $\mathrm{Fe}$ and $\mathrm{Zn}$. Faecal recoveries of rare earths with individual samples and composites of sequential outputs are evaluated with reference to the variables of the faecal excretion kinetics of rare earths. In compilation of the results of the two investigations, they are identified as the marker recovery and the marker-tracer investigation.

\section{Methods}

\section{Subjects and ethical approval}

Six subjects (five male and one female) and seven subjects (six male and one female) in good health and pursuing normal daily activities participated in the marker recovery and the marker-tracer investigation respectively. Five subjects who participated in the first were also subjects in the second investigation. The mean values and ranges of physical characteristics of the subjects are provided in Table 1. Ethical approval for the investigations was provided by The Joint Ethical Committee of Grampian Health Board and The University of Aberdeen, and The Research Ethics Committee of Glasgow Royal Infirmary, Greater Glasgow Health Board. Each subject gave informed written consent.

\section{Study design, preparation and administration of markers and tracers, and faecal collections}

The marker recovery investigation. Non-absorbability, reproducibility of faecal excretion profile, and variables related to excretion kinetics were investigated for five selected rare earths. The doses of rare earths given to the subjects were calculated with reference to limits of determination of rare earths by nuclear activation analysis (NAA). Sm, La, Yb, Tb and Eu had the lowest limits of determination in ascending order, when they were irradiated for $6 \mathrm{~h}$ in a flux of $4.2 \times 10^{12} \mathrm{n} / \mathrm{cm}^{2}$ pers and counted on a $130 \mathrm{cc}$ HPGe detector (Tennelec Inc., Oak Ridge, TN, USA) $2 \mathrm{~d}$ after the irradiation. The doses (for which the minimum detectable amounts were required to be $0.1 \%$ of the total input with $1-2 \%$ precision for $1 \mathrm{~h}$ count) were (mg): La 1, Sm 1, Eu 10, Tb 7.5 and Yb 5. The inputs for the same rare earths used by Luckey et al. (1977) were $60,39,15 \cdot 5,50$, and $30 \mathrm{mg}$ respectively.

Solutions of the rare earths were prepared from Specpure oxides (Jonson Matthey, Material Technology, Royston, Herts., UK) to contain $1 \mathrm{mg} \mathrm{La} / \mathrm{ml}, 1 \mathrm{mg} \mathrm{Sm} / \mathrm{ml}, 10 \mathrm{mg}$ $\mathrm{Eu} / \mathrm{ml}, 7.5 \mathrm{mg} \mathrm{Tb} / \mathrm{ml}$, and $5 \mathrm{mg} \mathrm{Yb} / \mathrm{ml}$ in $0.1 \mathrm{M}-\mathrm{HCl}$. The contents of the rare earth solutions were confirmed by

Table 1. Physical and haematological characteristics of the subjects participating in the marker recovery (five male and one female) and the marker-tracer investigation (six male and one female)

(Mean values and standard deviations, and ranges)

\begin{tabular}{|c|c|c|c|c|c|c|}
\hline & \multicolumn{3}{|c|}{ Marker recovery investigation } & \multicolumn{3}{|c|}{ Marker-tracer investigation } \\
\hline & Mean & SD & Range & Mean & SD & Range \\
\hline Age (years) & 42 & 11 & $28-56$ & 40 & 12 & $29-57$ \\
\hline Weight $(\mathrm{kg})$ & 72 & 15 & $55-95$ & 74 & 13 & $55-95$ \\
\hline Height $(\mathrm{m})$ & 1.74 & $0 \cdot 10$ & $1.57-1.85$ & 1.73 & 0.10 & $1.57-1.85$ \\
\hline $\mathrm{Hb}(\mathrm{g} / \mathrm{l})$ & 151 & 13 & $135-168$ & 150 & 12 & $135-168$ \\
\hline $\operatorname{RBC}\left(\times 10^{12} / \mathrm{l}\right)$ & 4.8 & 0.4 & $4 \cdot 5-5 \cdot 3$ & 4.9 & 0.4 & $4 \cdot 5-5 \cdot 3$ \\
\hline Ferritin $(\mu \mathrm{g} / \mathrm{l})$ & 94 & 31 & $49-131$ & 96 & 40 & $47-152$ \\
\hline
\end{tabular}

$\mathrm{Hb}$, haemoglobin; RBC, red blood cells. 
NAA. Subjects drank $1 \mathrm{ml}$ of the solution diluted to $20 \mathrm{ml}$ with distilled water with their lunch. They took two further water rinses of the container to ensure total consumption.

Subjects were provided with a faecal sample collection system (a toilet ring and 'biohazard' polyethylene bags) as described by Hinton et al. (1969). All stools were collected from the day before administration (for baseline samples) and for the succeeding week. Times of bowel movements were recorded with reference to the time of rare earths administration.

The marker-tracer investigation. The investigation was performed for two modes of intakes, a solution (Magnusson et al. 1981) and a wheat-based Farina meal (JD Cook, Kansas University Medical Center, Kansas City, KS, USA) (Forbes et al. 1989), because wheat is consumed worldwide. Both were suggested as reference inputs for studies of measurement of absorption of Fe. Zn was also included in the meal in anticipation of wider applicability of the marker recovery approach. The standard solution containing $\mathrm{Fe}$ labelled with ${ }^{57} \mathrm{Fe}$ and containing the $\mathrm{Sm}$ marker, and a Farina meal containing Fe labelled with ${ }^{58} \mathrm{Fe}$, $\mathrm{Zn}$ labelled with ${ }^{70} \mathrm{Zn}$, and containing the $\mathrm{Yb}$ marker were administered to the subjects with an interval of $3 \mathrm{~d}$. The amounts of the markers used were $1 \mathrm{mg}$ of each. ${ }^{57} \mathrm{Fe}$ tracer $(2 \mathrm{mg})$ for the standard solution, and $1 \mathrm{mg}{ }^{58} \mathrm{Fe}$ and ${ }^{70} \mathrm{Zn}$ tracers for the meal were used. Fe, enriched $95.5 \%$ in ${ }^{57} \mathrm{Fe}$ (natural abundance $2.2 \%$ ) and $91.90 \%$ in ${ }^{58} \mathrm{Fe}$ (natural abundance $0.28 \%$ ), and $\mathrm{Zn}$, enriched $74.1 \%$ in ${ }^{70} \mathrm{Zn}$ (natural abundance $0.6 \%$ ), were obtained from Europa Scientific Ltd (Crewe, Ches., UK) in metallic form.

For consumption of the standard solution, a solution of $\mathrm{Fe}$ in $0.05 \mathrm{M}-\mathrm{H}_{2} \mathrm{SO}_{4}(50 \mathrm{ml})$ was prepared to contain $0.46 \mathrm{mg} \mathrm{Fe} / \mathrm{ml}$, including $0.29 \mathrm{mg}{ }^{57} \mathrm{Fe} / \mathrm{ml}$. Sm marker solutions were prepared to contain $1.0 \mathrm{mg} \mathrm{Sm} / \mathrm{ml}$ in $0.01 \mathrm{M}-\mathrm{H}_{2} \mathrm{SO}_{4}$. For consumption with the Farina meal, solutions of $\mathrm{Fe}$ and $\mathrm{Zn}$ in $0.01 \mathrm{M}-\mathrm{HCl}(15 \mathrm{ml})$ were prepared to contain $1.55 \mathrm{mg} \mathrm{Fe} / \mathrm{ml}$, including $0.50 \mathrm{mg}$ ${ }^{58} \mathrm{Fe} / \mathrm{ml}$, and $1.54 \mathrm{mg} \mathrm{Zn} / \mathrm{ml}$, containing $0.50 \mathrm{mg}{ }^{70} \mathrm{Zn} / \mathrm{ml}$. $\mathrm{Yb}$ marker solution was prepared to contain $1.0 \mathrm{mg} \mathrm{Yb/ml}$ in $0.01 \mathrm{M}-\mathrm{HCl}$. The isotopic and marker contents of the solutions were confirmed by NAA $\left(\mathrm{Sm}, \mathrm{Yb},{ }^{58} \mathrm{Fe}\right.$ and $\left.{ }^{70} \mathrm{Zn}\right)$ and inductively-coupled plasma (ICP)-MS $\left({ }^{57} \mathrm{Fe}\right)$.

After an overnight fast, subjects consumed $7 \mathrm{ml}{ }^{57} \mathrm{Fe}$ solution $\left(3.2 \mathrm{mg}\right.$ Fe including $\left.2 \mathrm{mg}{ }^{57} \mathrm{Fe}\right)$ diluted to $50 \mathrm{ml}$ with demineralised water, with addition of $1 \mathrm{ml} \mathrm{Sm}$ marker solution (1 mg Sm) and $20 \mathrm{mg}$ ascorbic acid to enhance absorption of Fe, as suggested by Cook et al. 1991. After complete consumption of the solution, two rinses of water were also taken to ensure total consumption. The subjects did not take any food or drink for the following $3 \mathrm{~h}$. Subjects were provided with a commode collection system (Sage Products Inc., Crystal Lake, IL, USA) to collect stool samples. Faecal samples were collected from the day before the administration of solution and continued for $10 \mathrm{~d}$. Urine samples were collected before (baseline) and after the administration of the solution for a period of $24 \mathrm{~h}$ to compare the levels of Sm with those of the baseline samples.

After consumption of the standard solution $(3 \mathrm{~d})$, the subjects, having fasted overnight, were given the Farina meal. The Farina flour-based meal was prepared as described by Forbes et al. (1989). Immediately after preparation of the meal, $2 \mathrm{ml}{ }^{58} \mathrm{Fe}(3 \mathrm{mg} \mathrm{Fe}$ including $1 \mathrm{mg}{ }^{58} \mathrm{Fe}$ ), $2 \mathrm{ml}{ }^{70} \mathrm{Zn} \mathrm{(3} \mathrm{mg} \mathrm{Zn} \mathrm{including} 1 \mathrm{mg}{ }^{70} \mathrm{Zn}$ ), and $1 \mathrm{ml} \mathrm{Yb}$ marker ( $1 \mathrm{mg} \mathrm{Yb})$ solutions were added to each portion; these were then stirred for $2 \mathrm{~min}$. Butter (14 g) and sugar $(24 \mathrm{~g})$ were then added to each portion of the meal. Portions were mixed well, and served with whole milk while they were hot. After complete consumption of the meals, serving bowls were rinsed with milk which was then drunk to ensure total consumption. No further food or drink was taken for $3 \mathrm{~h}$. Urine samples were also collected for $24 \mathrm{~h}$ after the meal consumption to compare the levels of $\mathrm{Yb}$ with those of the baseline samples. Collection of stools terminated 1 week after consumption of the meal. Times of bowel movements were recorded with reference to the time of administration of the test meal.

Individual faecal samples were stored at $-20^{\circ} \mathrm{C}$ until analysis. Samples collected for the marker recovery investigation were autoclaved and those collected for the marker-tracer investigation were irradiated with a ${ }^{60} \mathrm{Co} \gamma$ source, receiving $75000 \mathrm{~Sv}$ to sterilise; each method of sterilisation was appropriate for the collection system. The samples were then oven-dried, ashed at $450^{\circ} \mathrm{C}$ for $16-24 \mathrm{~h}$, ground to provide homogeneity, and stored in plastic containers for further use.

\section{Analytical techniques}

NAA was the principal analytical technique for determination of rare earths and isotopic tracers used. The introduction of ICP-MS arose since ${ }^{57} \mathrm{Fe}$ produces a stable activation product. ICP-MS was also employed to determine baseline levels of rare earths in faecal and urine samples because the levels were very low and their determination by NAA was not feasible at the neutron flux availability of the reactor.

Total $\mathrm{Fe}$ and $\mathrm{Zn}$ contents of faecal samples were determined by atomic absorption spectrometry, to account for the isotopic contribution of $\mathrm{Fe}$ and $\mathrm{Zn}$ of natural composition to enrichment in faecal pool.

All chemicals used in sample preparation and analyses were of high purity and suitable for trace metal analysis. Acids, all Aristar (BDH, Poole, Dorset UK), rare earth oxides and metal standard solutions, all Specpure (Jonson Matthey), and ion-exchange resins (Bio-Rad, Hemel Hempstead, Herts, UK) were used.

\section{Determination of rare earth elements}

The rare earths contents of ashed faecal samples were determined by NAA after a pre-irradiation separation. Fractions of each of the ashed faecal samples $(200 \mathrm{mg}$ ) were dissolved in $10 \mathrm{ml}$ aqua regia (concentrated $\mathrm{HNO}_{3}-$ concentrated $\mathrm{HCl}$ ) by heating with addition of $200 \mu \mathrm{g} \mathrm{Pr}$ added as a separation yield tracer. The solutions were evaporated to near dryness and diluted to $50 \mathrm{ml}$ with $1 \mathrm{M}$ $\mathrm{HNO}_{3}$. They were then passed through cation-exchange columns (100-200 mesh Bio-Rad AG 50W-X8; Bio-Rad). The rare earth contents of the columns were eluted by modification of a procedure previously applied to geological samples (Crock \& Lichte, 1982). The eluents 
containing rare earths were evaporated to reduce the final volumes to $10 \mathrm{ml}$. The rare earth contents of the eluents were determined by NAA (Ulusoy, 1996).

The rare earth contents of the baseline faecal samples and urine samples were determined by ICP-MS. Ashed faecal samples $(0.1 \mathrm{~g})$ were dissolved and evaporated as described above and diluted with addition of $0.25 \mathrm{M}-\mathrm{HNO}_{3}$ to provide a sample concentration of $1 \mathrm{~g} / \mathrm{l}$. Fractions of collected urine samples $(100 \mathrm{ml})$ were heated to allow digestion with gradual addition of $16 \mathrm{M}-\mathrm{HNO}_{3}$ and $30 \%$ $\mathrm{H}_{2} \mathrm{O}_{2}$ until clear colourless solutions were obtained. The solutions were then made up to $100 \mathrm{ml}$. Acid digested samples $(5 \mathrm{ml})$ were diluted to $20 \mathrm{ml}$ with $0.25 \mathrm{M}-\mathrm{HNO}_{3}$. A PlasmaQuad STE11 (Fisons Instruments Elemental Analysis, Crawley, Sussex, UK) was used for analysis of the samples. The rare earth contents of the samples were determined by triplicate measurements.

\section{Determination of ${ }^{57} \mathrm{Fe},{ }^{58} \mathrm{Fe}$ and ${ }^{70} \mathrm{Zn}$ tracers}

Fractions of ashed faecal samples $(0.2 \mathrm{~g})$ were dissolved and evaporated to near dryness as described earlier. The residues were dissolved in $9 \mathrm{M}-\mathrm{HCl}$ and passed through anion-exchange columns (100-200 mesh Bio-Rad AG 1X8; Bio-Rad), previously equilibrated with $9 \mathrm{M}-\mathrm{HCl}$. The columns were washed with $5 \mathrm{ml} 4 \mathrm{M}-\mathrm{HCl} ; \mathrm{Fe}$ and $\mathrm{Zn}$ contents of the columns were then eluted with $50 \mathrm{ml} 0.5 \mathrm{M}$ and $70 \mathrm{ml} 0.005 \mathrm{M}-\mathrm{HCl}$. The isotopic contents of the column-separated samples were determined by NAA $\left({ }^{58} \mathrm{Fe}\right.$ and ${ }^{70} \mathrm{Zn}$ ) or ICP-MS $\left({ }^{57} \mathrm{Fe}\right)$ (Ulusoy, 1996). Post-irradiation separation procedure was also required for removal of residual ${ }^{56} \mathrm{Mn}$ activity by precipitation of $\mathrm{MnO}_{2}$ (Janghorbani et al. 1980) for determination of ${ }^{70} \mathrm{Zn}$.

\section{Determination of iron and zinc by atomic absorption spectroscopy}

Ashed faecal samples $(0 \cdot 1 \mathrm{~g})$ were dissolved in $5 \mathrm{ml}$ aqua regia and evaporated to dryness. The residues were redissolved in $5 \mathrm{ml} 11 \mathrm{M}-\mathrm{HCl}$ and diluted to $100 \mathrm{ml}$. The $\mathrm{Fe}$ and $\mathrm{Zn}$ contents of the samples were determined with a Philips (Model PU9100) flame atomic absorption spectrophotometer (Philips, Cambridge, Cambs., UK).

Accuracy of all measurements of the isotopic tracers and elemental analysis of $\mathrm{Fe}$ and $\mathrm{Zn}$ was confirmed by determination of the contents of bovine liver standard (NBS 1577a; National Bureau of Standards, Gaithersburg, FL, USA) which had been subjected to the same chemical treatment as the samples. $\mathrm{Fe}$ and $\mathrm{Zn}$ concentrations in the NBS 1577a were found to be respectively $(n 4, \mu \mathrm{g} / \mathrm{g}): 187$ (SD 4) and 124 (SD 3) by NAA; 190 (SD 2) (for Fe only) by ICP-MS; and 189 (SD 7) and 122 (SD 8 ) $\mu \mathrm{g} / \mathrm{g}$ dry sample by AAS. These values agreed with the certified content of this standard (194 (SD 10) and 123 (SD 8) $\mu \mathrm{g} / \mathrm{g}$ dry sample for $\mathrm{Fe}$ and $\mathrm{Zn}$ respectively).

\section{Results}

Calculations and statistical analysis

Recovery of the rare earths from individual samples $\left(\mathrm{M}_{\mathrm{i}}\right)$ were calculated as fractions of the doses administered, taking account of the concentrations found in faecal samples provided before the administration. Recoveries from sequential individual samples were summed to obtain cumulative values. Total recoveries were obtained by summation of the fractional recoveries with the first to last of sequential individual samples. Fractional faecal recoveries of non-absorbed tracers with individual samples $\left(\mathrm{I}_{\mathrm{i}}\right)$ were calculated from:

$$
I_{i}=\left(I_{f}-E_{f} R_{e}\right) /\left(I_{d}\left(1-R_{e}\right)\right),
$$

where $I_{f}$ is the amount of isotope consisting of enriched isotopic tracer excreted and endogenous contribution of enriching isotope determined by ICP-MS or NAA, $\mathrm{E}_{\mathrm{f}}$ is amount of trace element of interest determined by atomic absorption spectrometry, $R_{e}$ is natural abundance of enriching isotope, and $I_{d}$ is amount of enriched isotopic tracer provided with the dose. Cumulative and total recoveries of the tracers in the sequential individual samples and total outputs were also obtained by summation of the recoveries as calculated from markers. Fractional absorption of the tracers $\left(A_{i}\right)$ were derived from $A_{i}=$ $1-\left(\mathrm{I}_{\mathrm{i}} / \mathrm{M}_{\mathrm{i}}\right)$ (see Appendix). The same formula was applied to calculate absorption for the cumulative or total collections by considering the relevant recoveries of marker and tracer. The recoveries of unabsorbed tracers (cumulative percentage of dose excreted):recoveries of markers ratios were evaluated to examine whether excretion kinetics of markers and tracers were identical.

Statistical significance of the differences between sample mean values was evaluated using two-tailed $t$ test.

\section{Rare earth element recoveries}

The mean values and ranges of concentrations of rare earths determined in baseline faecal samples obtained from the marker recovery and marker-tracer investigations, which were performed with an interval of 1 year (1992 and 1993)

Table 2. Natural (baseline) levels of rare earth elements in ashed faecal samples*

(Mean values and standard deviations, and ranges for thirteen samples)

\begin{tabular}{lccc}
\hline & \multicolumn{3}{c}{$\begin{array}{c}\text { Mean REE concentrations in } \\
\text { faecal samples }(\mu \mathrm{g} / \mathrm{g} \text { ash) }\end{array}$} \\
\cline { 2 - 4 } $\mathrm{REE}$ & Mean & $\mathrm{SD}$ & Range \\
\hline $\mathrm{La}$ & 1.35 & 0.52 & $0.81-2.16$ \\
$\mathrm{Ce}$ & 1.76 & 0.68 & $1.15-3.18$ \\
$\mathrm{Pr}$ & 0.31 & 0.11 & $0.19-0.49$ \\
$\mathrm{Nd}$ & 1.04 & 0.33 & $0.69-1.55$ \\
$\mathrm{Sm}$ & 0.18 & 0.03 & $0.15-0.22$ \\
$\mathrm{Eu}$ & 0.09 & 0.07 & $0.04-0.23$ \\
$\mathrm{Gd}$ & 0.19 & 0.06 & $0.11-0.27$ \\
$\mathrm{~Tb}$ & 0.06 & 0.05 & $0.02-0.11$ \\
$\mathrm{Dy}$ & 0.16 & 0.04 & $0.09-0.21$ \\
$\mathrm{Ho}$ & 0.03 & 0.01 & $0.02-0.04$ \\
$\mathrm{Er}$ & 0.08 & 0.03 & $0.01-0.12$ \\
$\mathrm{Tm}$ & 0.02 & 0.003 & $0.01-0.02$ \\
$\mathrm{Yb}$ & 0.29 & 0.26 & $0.10-0.86$ \\
$\mathrm{Lu}$ & 0.02 & 0.004 & $0.01-0.02$ \\
\hline $\mathrm{BEE}$ & & &
\end{tabular}

REE, rare earth element.

* For details of analytical procedures see p. 607. 


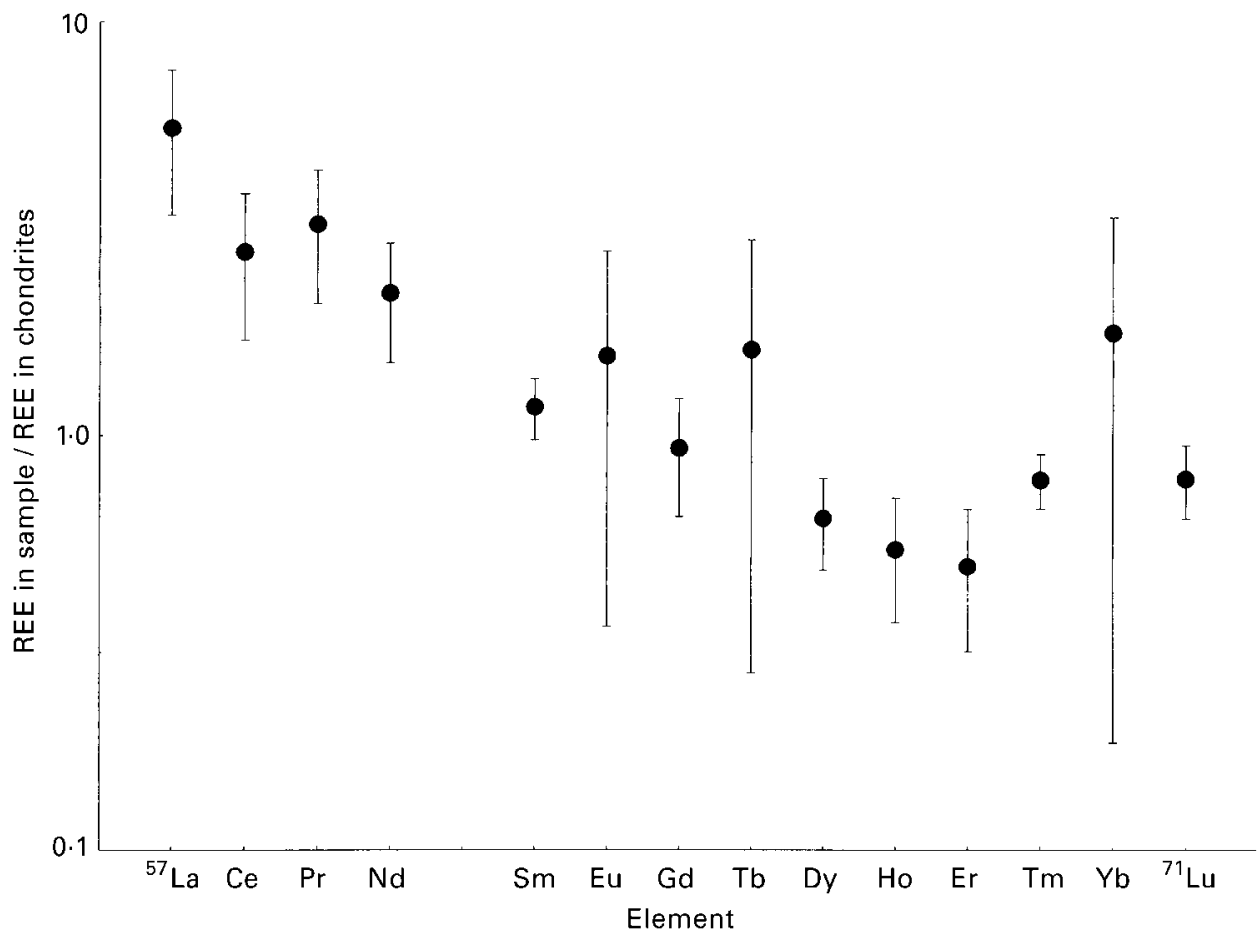

Fig. 1. Chondrite-normalised rare earth element (REE) pattern in faecal samples (rare earth element concentrations in natural samples are usually normalised to a common reference standard, which most commonly comprises the values for chondritic meteorites. Chondritic meteorites were chosen because they were thought to be relatively unfractionated sample of solar system dating from the original nucleosynthesis). Values are means for thirteen samples with standard deviations represented by vertical bars.

are provided in Table 2. The level of baseline concentrations is evidence for the usefulness of rare earths as markers. The mean of rare earth concentrations, normalised to abundance in chondritic meteorites as a function of the atomic numbers (Laul \& Gosselin, 1989), is provided in Fig. 1. The descending trend for the normalised concentrations is characteristic of rare earths in natural materials and can also be taken as a supporting evidence for the accuracy of analyses.

The recoveries of the rare earths obtained from both investigations are provided in Table 3. For the marker recovery investigation, the contributions of baseline levels to recoveries were not significant, except for La. However, the difference between the recoveries of $\mathrm{La}$ and $\mathrm{Sm}, \mathrm{Eu}$, $\mathrm{Tb}$, and $\mathrm{Yb}$ was not significant when account was taken of the natural level of $\mathrm{La}$. For $\mathrm{Sm}, \mathrm{Eu}, \mathrm{Tb}$, and $\mathrm{Yb}$, baseline levels were always less than $1 \%$ of the dose administered. Table 3 also provides the recoveries of $\mathrm{Sm}$ marker consumed with a solution and $\mathrm{Yb}$ marker consumed with a Farina meal.

The mean of recoveries for the five rare earths obtained in the marker recovery investigation was $94 \cdot 1$ (SD 4.2) $\%$. The $\mathrm{CV}$ for the mean of total recoveries of the five rare earths (being similar to those of recoveries with individual

Table 3. Faecal recoveries of the rare earth elements obtained from the recovery investigation and its reproducibility, and the recoveries of Sm and $\mathrm{Yb}$ from the marker-tracer investigation*

\begin{tabular}{|c|c|c|c|c|c|c|c|c|c|c|c|}
\hline \multirow[b]{3}{*}{ Subject no. } & \multirow[b]{3}{*}{ Sex } & \multicolumn{10}{|c|}{ Recovery of the rare earth elements ( $\%$ dose consumed) } \\
\hline & & \multicolumn{8}{|c|}{ Recovery investigation } & \multicolumn{2}{|c|}{ Marker-tracer investigation } \\
\hline & & $\mathrm{La}_{\mathrm{b}} \dagger$ & $\mathrm{La}_{\mathrm{a}} \dagger$ & $\mathrm{Sm}$ & Eu & $\mathrm{Tb}$ & $\mathrm{Yb}$ & Mean & $\mathrm{SD}$ & $\mathrm{Sm}$ & $\mathrm{Yb}$ \\
\hline 1 & M & 101 & $98 \cdot 1$ & $96 \cdot 9$ & 95.4 & $97 \cdot 1$ & $95 \cdot 9$ & $96 \cdot 9$ & 0.4 & 105 & 100 \\
\hline 2 & M & 104 & 99.9 & 101 & 101 & 101 & 98.6 & 100 & 0.4 & 98.9 & 105 \\
\hline 3 & M & 97.0 & 90.5 & 92.7 & 92.7 & 91.4 & 90.5 & 91.1 & 0.4 & 102 & 98.4 \\
\hline 4 & $\mathrm{M}$ & 100 & 93.9 & 93.2 & 94.4 & 94.6 & 94.5 & 94.2 & 0.2 & 108 & 101 \\
\hline 5 & $\mathrm{~F}$ & 89.4 & $86 \cdot 1$ & 89.7 & 88.9 & 87.9 & $87 \cdot 8$ & $88 \cdot 1$ & 0.4 & 101 & 101 \\
\hline 6 & M & 101 & 97.6 & $92 \cdot 0$ & 94.0 & 94.9 & 93.9 & 94.5 & 0.4 & 100 & 97.2 \\
\hline 7 & M & & & & & & & & & 103 & $96 \cdot 1$ \\
\hline Mean & & 98.7 & 94.3 & 94.3 & 94.4 & 94.5 & 93.5 & 94.1 & & 103 & 99.8 \\
\hline SD & & $5 \cdot 1$ & $5 \cdot 3$ & $4 \cdot 0$ & 3.9 & 4.5 & 3.9 & $4 \cdot 2$ & & 3.1 & 2.9 \\
\hline
\end{tabular}

M, male; F, female.

*For details of subjects see Table 1; for details of procedures see p. 607.

† Recoveries of $L a$ are provided before $\left(L a_{b}\right)$ and after $\left(L_{a}\right)$ subtraction of its baseline level (see Table 2; the mean of the five rare earth elements includes baselinecorrected La recoveries). 
samples, i.e. showing an identical recovery profile specific to each subject) were less than 1 (SD $0 \cdot 2-0 \cdot 4) \%$ for all subjects, compared with 5 (SD 3.9-8.4) \% as obtained by Luckey et al. (1977). Quantitative recovery was obtained for only one subject. Non-quantitative recoveries were attributable to incomplete sample collection (e.g. exclusion of toilet paper), losses during processing associated with the sample collection system, and procedure followed for sample preparation, particularly autoclave sterilisation. The identifiable effect of baseline of $\mathrm{La}$ on its recoveries implies that the fraction of the doses administered absorbed by the intestine could not be more than a fraction that is comparable with the contribution of baseline concentrations of the rare earths to its recoveries.

The recoveries obtained in the marker-tracer investigation were quantitative, providing a mean of 103 (SD 3.1) \% for $\mathrm{Sm}$ and 99.8 (SD 2.9) \% for $\mathrm{Yb}$ (Table 3). This was achieved with strict subject cooperation, use of an improved collection system, and sterilisation by $\gamma$-irradiation. The design of commode collection system (Sage Products) was more convenient for the nature of sample collection and the procedure for sample processing (sterilisation, drying, and complete sample transfer for ashing) than the toilet ring-bag method (Hinton et al. 1969), so the possible losses due to collection system used was minimal. The toilet ring-bag method was used for studies with radio-opaque markers that were determined by $\mathrm{x}$-ray, for which sample transfer was unnecessary.

The mean concentrations of $\mathrm{Sm}$ in $24 \mathrm{~h}$ urine collections provided before any administration (baseline), after consumption of $\mathrm{Sm}$ with the standard solution of $\mathrm{Fe}$ with ascorbic acid, and after consumption of the standard meal ( $3 \mathrm{~d}$ after the drink) were found to be 0.15 (SD 0.04) $\mu \mathrm{g} / \mathrm{l}$, 1.25 (SD 0.4) $\mu \mathrm{g} / \mathrm{l}$, and 0.16 (SD 0.08) $\mu \mathrm{g} / \mathrm{l}$ respectively. The level of $\mathrm{Sm}$ in samples provided after its consumption was significantly different from that found for baseline samples $(P<0 \cdot 001)$, whilst there was no significant difference between the level of $\mathrm{Sm}$ in baseline samples and that in samples provided after the meal $(P>0.05)$. This showed that the fraction of Sm initially absorbed was excreted from the body during the time between the administrations ( $3 \mathrm{~d})$. In this context, it is worth noting that the results obtained by Kramsch et al. (1980), which indicated that when monkeys were fed a meal containing $40 \mathrm{mg} \mathrm{La} / \mathrm{kg}$ body weight, the level of $\mathrm{La}$ in circulating blood returned to natural levels after $12 \mathrm{~h}$. With assumption of a steady state between $\mathrm{Sm}$ in blood and urine, and a total blood volume of 5 litres, the level found in urine is equivalent to absorption of less than $1 \%$ of the dose administered. The slight absorption of $\mathrm{Sm}$ found in this investigation might be explained by the composition of the test drink onto which Sm is adsorbed within the intestine (Venugopal \& Luckey, 1975), or by ascorbic acid forming an absorbable complex with Sm (Hasegawa et al. 1988).

The mean of $\mathrm{Yb}$ concentrations for baseline samples and that for samples provided after consumption of the meal containing $\mathrm{Yb}$ were 0.14 (SD 0.07) $\mu \mathrm{g} / \mathrm{l}$ and 0.10 (SD 0.02) $\mu \mathrm{g} / \mathrm{l}$. There was no significant difference between the means $(P>0.05)$, suggesting that absorption of $\mathrm{Yb}$ is very low when it is administered with food, as found in previous investigations (Hutcheson et al. 1975; Luckey et al. 1975).
The mean cumulative recoveries of the five rare earths and $\mathrm{Yb}$ (both consumed with a meal) in the first two, three, and four faecal collections were $75 \%, 95 \%$ and $98 \%$ respectively, when expressed as percentage of the total excreted marker. The means of recoveries with composites of the first two and three samples were $90 \%$ and $98 \%$ for $\mathrm{Sm}$ consumed without food. In both investigations, recoveries with the fourth or fifth samples were less than $1 \%$, and the concentrations of the rare earths and accompanying tracers in the following samples $(6$ or $7 \mathrm{~d}$ after the administration) had returned to baseline levels. An example of faecal recovery profiles of $\mathrm{Sm}$ and $\mathrm{Yb}$ together with accompanying tracers is provided in Fig. 2 for one subject. The recovery of Sm with the first sample in which a fraction of the $\mathrm{Yb}$ was recovered was only a few percent of the dose administered. This shows that Sm marker and unabsorbed tracer (consumed with solution) had been almost totally excreted when $\mathrm{Yb}$ and tracer administered with a Farina meal entered the intestine.

The kinetics of digesta can be estimated from retention patterns and mean transit time of nutritional markers as described by Kotb \& Luckey (1972), Luckey (1979) and Metcalf et al. (1987). Retention patterns of the rare earths for each subject were evaluated to determine first appearance time (duration required for digesta to enter the excretion compartment) by extrapolating to $100 \%$ retained in the body, the gastrointestinal half-life of the rare earths, and time for quantitative excretion (Fig. 3). The means of the intestinal kinetic variables derived from the retention approach and the mean of mean transit times were compared to evaluate if there were any significant differences between the intestinal kinetic variables related to the mode of consumption (Table 4). The rare earths and $\mathrm{Yb}$ consumed with food show different kinetic variables than Sm consumed without food $(P<0 \cdot 01)$, except for the mean transit time $(P>0.05)$.

\section{Comparison of the intestinal kinetics of unabsorbed tracers and rare earth element markers and the absorption (intestinal uptake) of iron and zinc}

The fractional recoveries of unabsorbed tracer $\left({ }^{57} \mathrm{Fe}\right.$, and ${ }^{58} \mathrm{Fe}$ and ${ }^{70} \mathrm{Zn}$ ):fractional recoveries of the accompanying markers $(\mathrm{Sm}$ and $\mathrm{Yb}$ ) ratios, as percentages of their cumulative recoveries from the first two to five faecal samples provided after each administration, were calculated for individual stools and their sequential composites to establish the extent to which the markers duplicated the excretion profiles of the tracers. The ratios should not be significantly different from unity if the excretion kinetics of the markers and tracers are identical. The means of the ratios of recoveries and those of the absorptions calculated for ${ }^{57} \mathrm{Fe}$ tracer and $\mathrm{Sm}$ marker, and ${ }^{58} \mathrm{Fe}$ and ${ }^{70} \mathrm{Zn}$ tracers and $\mathrm{Yb}$ marker are provided in Table 5, Table 6 and Table 7 for all subjects.

For ${ }^{57} \mathrm{Fe}$ tracer and $\mathrm{Sm}$ marker consumed with the solution, the tracer:marker ratios calculated with reference to total recoveries from five faecal samples were significantly different from unity for individual samples and cumulative collection of the first two and three samples (Table 5). The deviations from unity were more significant 


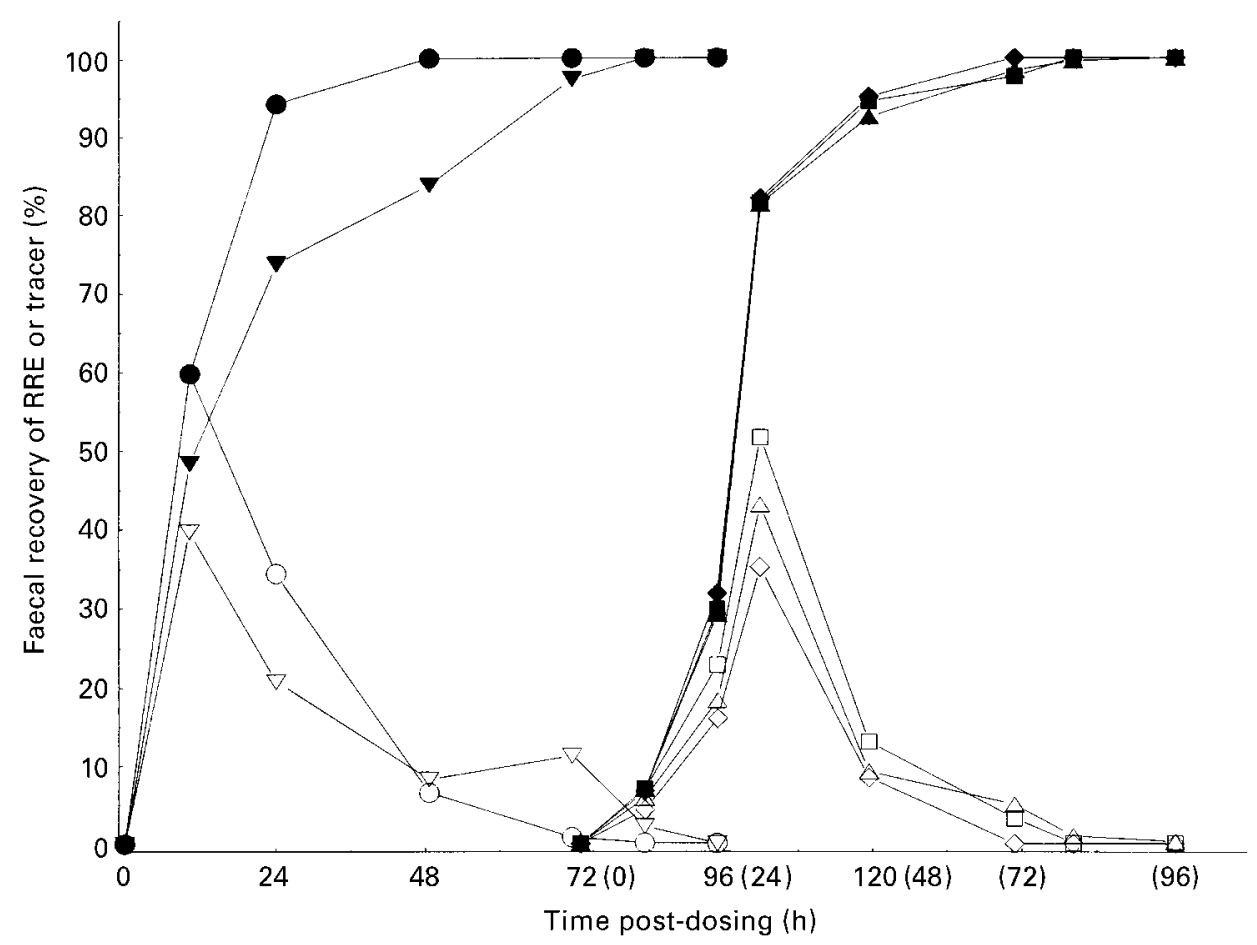

Fig. 2. Faecal profiles from one subject of recoveries of rare earth elements (REE) for individual faecal samples (as percentage of ingested dose: $\bigcirc, \mathrm{Sm} ; \nabla,{ }^{57} \mathrm{Fe} ; \square, \mathrm{Yb} ; \triangle,{ }^{58} \mathrm{Fe} ; \diamond,{ }^{70} \mathrm{Zn}$ ) and cumulative collection of faecal samples (as cumulative percentage of the dose excreted: $\bullet$, SM; $\boldsymbol{\nabla}$, ${ }^{57} \mathrm{Fe} ; \mathbf{\square}, \mathrm{Yb} ; \boldsymbol{\Lambda},{ }^{58} \mathrm{Fe} ;{ }^{70} \mathrm{Zn}$ ) obtained from the marker-tracer investigation, where $\mathrm{Sm}-{ }^{57} \mathrm{Fe}$, and $\mathrm{Yb}-{ }^{58} \mathrm{Fe}$ and ${ }^{70} \mathrm{Zn}$, were administered at a time interval of $3 \mathrm{~d}$. Data for cumulative recoveries illustrate the nearly identical excretion pattern of $\mathrm{Yb}$ and ${ }^{58} \mathrm{Fe}$ and ${ }^{70} \mathrm{Zn}$, unlike that of $\mathrm{Sm}$ and ${ }^{57} \mathrm{Fe}$.

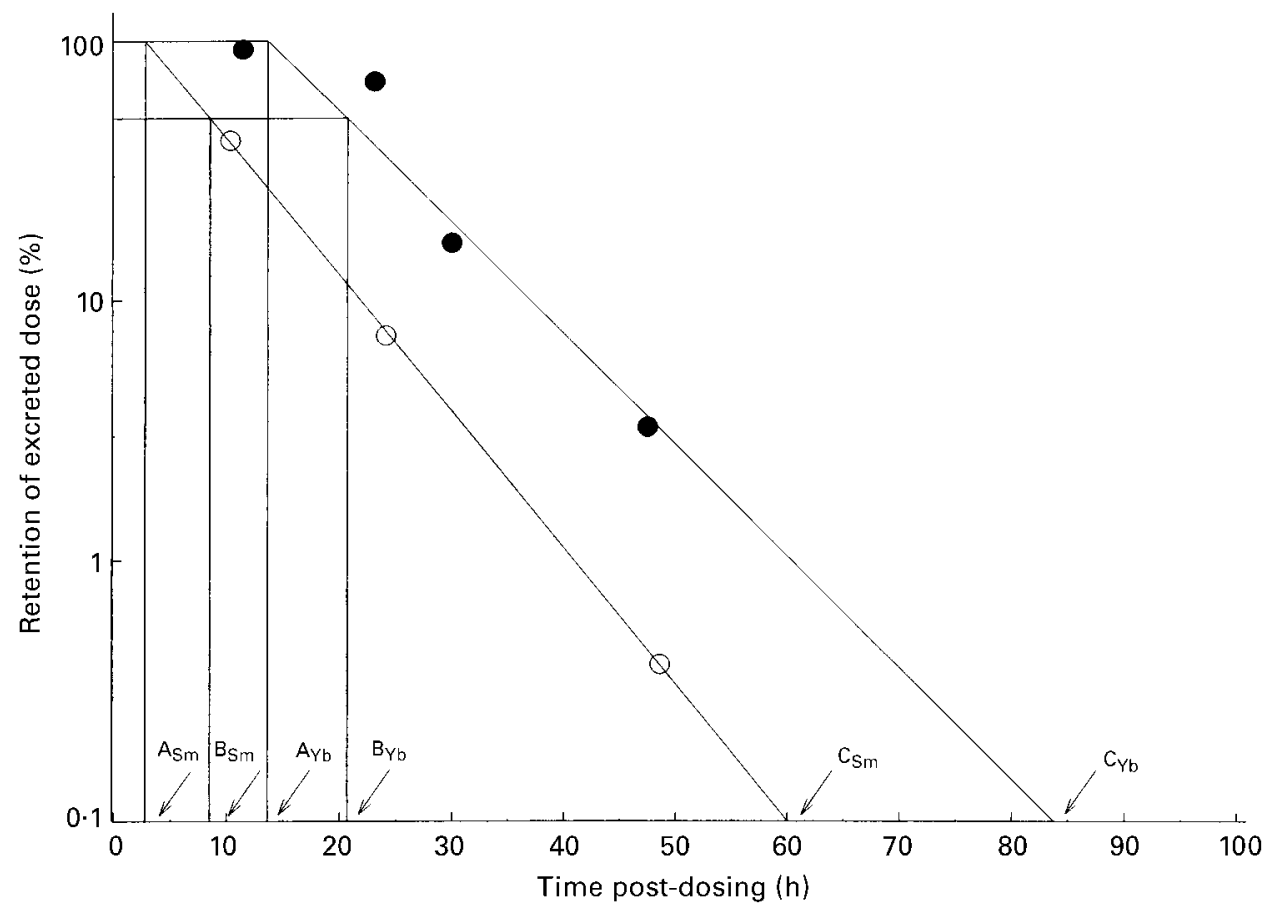

Fig. 3. Linearity of retention pattern for Sm consumed with a standard solution $\left(O ; r^{2} 0.999\right)$, and Yb consumed with a Farina meal JD Cook, Kansas University Medical Center, Kansas City, KS, USA) $\left(\bullet ; r^{2} 0.936\right)$, for one subject. For details of the composition of the meal see p. 607 . A, time of first appearance; B, gastrointestinal half-life; and $\mathrm{C}$, time for quantitative excretion. 
Table 4. Comparison of the mean values for intestinal kinetic variables: time of first appearance $\left(t_{0}\right)$, gastrointestinal half-life $\left(t_{1 / 2}\right)$, time for quantitative excretion $\left(\mathrm{t}_{\mathrm{q}}\right)$, and mean transit time $\left(\mathrm{t}_{\mathrm{m}}\right)$ obtained from the marker recovery and marker-tracer investigation ${ }^{*}$

(Mean values and standard deviations)

\begin{tabular}{|c|c|c|c|c|c|c|c|c|c|c|}
\hline & \multicolumn{10}{|c|}{ Kinetic variables for $n$ subjects (h) } \\
\hline & \multicolumn{6}{|c|}{ Marker recovery investigation $(n 6) \ddagger$} & \multicolumn{4}{|c|}{ Marker-tracer investigation $(n 7) \S$} \\
\hline & \multicolumn{2}{|c|}{ Sm } & \multicolumn{2}{|c|}{$\mathrm{Yb}$} & \multicolumn{2}{|c|}{ Five REE } & \multicolumn{2}{|c|}{$\mathrm{Yb}$} & \multicolumn{2}{|c|}{ Sm } \\
\hline & Mean & SD & Mean & SD & Mean & SD & Mean & SD & Mean & SD \\
\hline$t_{0}$ & 12 & $1 \cdot 3$ & 13 & $2 \cdot 0$ & $12^{* *}$ & 1.5 & $12^{\star *}$ & $3 \cdot 6$ & 5 & 1.9 \\
\hline$t_{1 / 2}$ & 23 & 3 & 23 & 3.3 & $23^{\star \star}$ & 3.2 & $21^{\star \star}$ & 3.6 & 14 & 3.0 \\
\hline$t_{q}$ & 80 & 19 & 82 & 25 & $82^{\star *}$ & 22 & $72^{\star \star}$ & $9 \cdot 6$ & 55 & $6 \cdot 3$ \\
\hline$t_{m}$ & 39 & $4 \cdot 1$ & 39 & 4.0 & $38 \dagger$ & $4 \cdot 0$ & 38† & 14 & 35 & 8.0 \\
\hline
\end{tabular}

REE, rare earth elements.

* For details of subjects see Table 1; for details of procedures see p. 607

The mean values of variables for the five rare earth elements (marker recovery investigation) and Yb (marker-tracer investigation) both consumed with food were significantly different from those obtained for $\mathrm{Sm}$ (marker-tracer investigation) consumed with a solution, except the mean transit time: ${ }^{\star \star} P<0 \cdot 01, \dagger P>0 \cdot 05$.

‡ The variables obtained for $\mathrm{Sm}, \mathrm{Yb}$, and the mean values of the five rare earth elements showed no significant difference for any comparison.

$\S$ For $\mathrm{Yb}$, one of seven subjects had a recovery higher than $50 \%$ in the first faecal sample provided after the administration, so the variables could not be evaluated.

for the third, fourth, and fifth individual samples, in which the recoveries of marker were only a few percent, or negligible. This shows the effect of endogenous excretion of the tracer initially taken up by the intestine. The closest value to unity was only obtained for the cumulative collection of the first four samples, which indicates that the endogenous excretion of the tracer is not significant after the fourth sample. A similar effect was also seen when the ratios of recoveries were evaluated with reference to the total recoveries from the first four, three, and two faecal samples. Deviations from unity for the first stools in any calculation implies that some time is required to attain a steady state between excretion kinetics of marker and tracer. Significant changes in favour of unity in the ratios for the second sample, and for cumulative collection of the first two and three samples are evidence for identical excretion kinetics of the marker and tracer. As found for the ratio of recoveries, the absorption of $\mathrm{Fe}$ obtained for the first two individual and the composites of the first two and three outputs were not significantly different from each other $(P>0.05)$, but were significantly different from those obtained for composites of the first four and five outputs $(P<0.05)$ (Table 7$)$. The non-significant difference for the mean value of absorptions obtained from the first faecal samples was due to high standard deviation of the mean. The significant difference for the composites of four and five samples was evidence for endogenous excretion of Fe initially taken up by the intestine, which implies that initial uptake of Fe consumed in a solution could be determined from the second individual sample or more reliably from the cumulative collection of the first two or three samples.

For ${ }^{58} \mathrm{Fe}$ and ${ }^{70} \mathrm{Zn}$ tracers, and $\mathrm{Yb}$ marker consumed with the Farina meal, the mean values of ratios of recoveries from the first two individual stools are very close to unity (Table 6). Deviations from unity appeared for the individual samples provided after the second and became more significant for the fourth and fifth samples, in which recoveries of tracers and marker were only a few percent or negligible. The insignificant difference from unity for the

Table 5. Recoveries of unabsorbed ${ }^{57} \mathrm{Fe}$ tracer:samarium marker ratios (consumed with a solution) obtained for sequential individual and cumulative collection of $n$ faecal samples*

(Mean values and standard deviations for seven subjects)

\begin{tabular}{|c|c|c|c|c|c|c|c|c|c|}
\hline & \multicolumn{5}{|c|}{ Sequential individual faecal samples } & \multicolumn{4}{|c|}{ Cumulative collection of $n$ samples } \\
\hline & 1 & 2 & 3 & 4 & 5 & 2 & 3 & 4 & 5 \\
\hline \multicolumn{10}{|c|}{ Ratio of recoveries with reference to cumulative recoveries from five samples $†$} \\
\hline Mean & 1.02 & 0.89 & 1.84 & $12 \cdot 8$ & $17 \cdot 2$ & 0.90 & 0.93 & 0.98 & 1.00 \\
\hline SD & 0.29 & $0 \cdot 17$ & 1.06 & $17 \cdot 9$ & $20 \cdot 9$ & 0.05 & 0.05 & 0.02 & \\
\hline \multicolumn{10}{|c|}{ Ratio of recoveries with reference to cumulative recoveries from four samples $\dagger$} \\
\hline Mean & 1.04 & 0.92 & 1.88 & $13 \cdot 1$ & & 0.92 & 0.94 & 1.00 & \\
\hline SD & 0.28 & $0 \cdot 18$ & 1.07 & $18 \cdot 2$ & & 0.06 & 0.04 & & \\
\hline \multicolumn{10}{|c|}{ Ratio of recoveries with reference to cumulative recoveries from three samples $\dagger$} \\
\hline Mean & $1 \cdot 10$ & 0.96 & 1.97 & & & 0.97 & 1.00 & & \\
\hline SD & 0.28 & $0 \cdot 17$ & 1.09 & & & 0.05 & & & \\
\hline \multicolumn{10}{|c|}{ Ratio of recoveries with reference to cumulative recoveries from two samples $\dagger$} \\
\hline Mean & 1.14 & 0.99 & & & & 1.00 & & & \\
\hline SD & 0.32 & $0 \cdot 17$ & & & & & & & \\
\hline
\end{tabular}

* For details of subjects see Table 1; for details of procedures see p. 607.

† The recoveries (as a percentage of the dose excreted with cumulative collection of five samples) of unabsorbed tracer ( ${ }^{57} \mathrm{Fe}$ ): $\mathrm{Sm}$ marker ratios for sequential individual and cumulative collection of the first two to five faecal samples. 'Ratio of recoveries with reference to cumulative collection of four, three and two samples' refers to the ratios of recoveries evaluated with reference to the percentage of dose excreted in the cumulative collection of the first four, three, and two faecal samples respectively. Tracer:marker ratio for the corresponding cumulative collection is 1.00 . The ratio closer to unity for any evaluation defines the closer excretion kinetics of the marker and tracer. 
Table 6. Recoveries of unabsorbed ${ }^{58} \mathrm{Fe}$ and ${ }^{70} \mathrm{Zn}$ tracers: $\mathrm{Yb}$ marker ratios (consumed with a meal) obtained for sequential individual and cumulative collection $n$ faecal samples*

(Mean values and standard deviations for seven subjects)

\begin{tabular}{|c|c|c|c|c|c|c|c|c|c|}
\hline & \multicolumn{5}{|c|}{ Individual faecal samples } & \multicolumn{4}{|c|}{ Cumulative collection of $n$ samples } \\
\hline & 1 & 2 & 3 & 4 & 5 & 2 & 3 & 4 & 5 \\
\hline \multicolumn{10}{|c|}{ For ${ }^{58} \mathrm{Fe}$ tracer and $\mathrm{Yb}$ marker } \\
\hline \multicolumn{10}{|c|}{ Ratio of recoveries, \% total unabsorbed tracer:\% total marker recovery from five samples $\dagger$} \\
\hline Mean & 0.98 & 1.00 & 1.08 & $2 \cdot 24$ & 4.43 & 0.98 & 0.98 & 0.99 & 1.00 \\
\hline SD & 0.03 & 0.05 & $0 \cdot 16$ & $1 \cdot 10$ & 3.65 & 0.02 & 0.01 & 0.01 & \\
\hline \multicolumn{10}{|c|}{ Ratio of recoveries with reference to total recoveries from four samples $\dagger$} \\
\hline Mean & 0.98 & 1.01 & 1.09 & $2 \cdot 26$ & & 0.99 & 0.99 & 1.00 & \\
\hline SD & 0.03 & 0.05 & $0 \cdot 16$ & $1 \cdot 10$ & & 0.02 & 0.01 & & \\
\hline \multicolumn{10}{|c|}{ Ratio of recoveries with reference to total recoveries from three samples $\dagger$} \\
\hline Mean & 0.99 & 1.02 & $1 \cdot 10$ & & & 0.99 & 1.00 & & \\
\hline SD & 0.02 & 0.06 & 0.17 & & & 0.01 & & & \\
\hline \multicolumn{10}{|c|}{ Ratio of recoveries with reference to total recoveries from two samplest } \\
\hline Mean & 1.00 & 1.03 & & & & 1.00 & & & \\
\hline SD & 0.02 & 0.05 & & & & & & & \\
\hline \multicolumn{10}{|c|}{ For ${ }^{70} \mathrm{Zn}$ tracer and $\mathrm{Yb}$ marker } \\
\hline \multicolumn{10}{|c|}{ Ratio of recoveries, \% total unabsorbed tracer:\% total marker recovery from five samples† } \\
\hline Mean & 0.99 & 1.01 & 0.92 & 1.30 & 0.08 & 1.01 & 1.01 & 1.00 & 1.00 \\
\hline SD & 0.04 & 0.05 & 0.17 & 1.45 & 0.19 & 0.02 & 0.02 & 0.00 & \\
\hline \multicolumn{10}{|c|}{ Ratio of recoveries with reference to total recoveries from four samples $\dagger$} \\
\hline Mean & 0.98 & 1.00 & 0.91 & 1.29 & & 1.00 & 1.00 & 1.00 & \\
\hline SD & 0.05 & 0.04 & 0.16 & 1.45 & & 0.01 & 0.01 & & \\
\hline \multicolumn{10}{|c|}{ Ratio of recoveries with reference to total recoveries from three samplest } \\
\hline Mean & 0.98 & 1.00 & 0.91 & & & 1.00 & 1.00 & & \\
\hline SD & 0.05 & 0.03 & $0 \cdot 16$ & & & 0.01 & & & \\
\hline \multicolumn{10}{|c|}{ Ratio of recoveries with reference to total recoveries from two samplest } \\
\hline Mean & 0.98 & 1.00 & & & & 1.00 & & & \\
\hline SD & 0.05 & 0.04 & & & & & & & \\
\hline
\end{tabular}

* For details of subjects see Table 1; for details of procedures see p. 607.

† The ratios of recoveries (as a percentage of the dose excreted with cumulative collection of five samples) of unabsorbed tracer ( ${ }^{57} \mathrm{Fe}$ ): $\mathrm{Sm}$ marker for sequential individual and cumulative collection of the first two to five faecal samples. 'Ratio of recoveries with reference to total recoveries with four, three and two samples' refers to the ratio of recoveries evaluated with reference to the percentage of dose excreted with cumulative collection of the first four, three, and two faecal samples respectively. Tracer:marker ratio for the corresponding cumulative collection is 1.00 . The ratio closer to unity for any evaluation defines the closer excretion kinetics of the marker and tracer.

Table 7. Apparent absorption of iron determined with ${ }^{57} \mathrm{Fe}$ tracer and samarium marker consumed with a standard solution, and absorption of iron and zinc determined with ${ }^{58} \mathrm{Fe}$ and ${ }^{70} \mathrm{Zn}$ tracers and ytterbium marker consumed with a Farina mealt‡

(Mean values and standard deviations, ranges, and medians for seven subjects)

\begin{tabular}{|c|c|c|c|c|c|c|}
\hline & \multicolumn{6}{|c|}{ Absorption (\% dose consumed)§ } \\
\hline & \multicolumn{2}{|c|}{ Individual samples } & \multicolumn{4}{|c|}{ Cumulative collection of $n$ samples } \\
\hline & First & Second & 2 & 3 & 4 & 5 \\
\hline \multicolumn{7}{|c|}{ Results for ${ }^{57} \mathrm{Fe}$} \\
\hline Mean & $24 \cdot 0^{*}$ & $30 \cdot 7^{\star}$ & $32.4^{*}$ & $30.4^{*}$ & 24.8 & $22 \cdot 9$ \\
\hline SD & $16 \cdot 8$ & $16 \cdot 4$ & $15 \cdot 3$ & $13 \cdot 8$ & $16 \cdot 3$ & $17 \cdot 2$ \\
\hline Range & $6 \cdot 1-54.9$ & $6 \cdot 8-55 \cdot 1$ & $9 \cdot 3-49 \cdot 6$ & $9 \cdot 5-48 \cdot 0$ & $7 \cdot 9-46 \cdot 5$ & $4.9-45.5$ \\
\hline Median & $23 \cdot 7$ & $33 \cdot 3$ & $36 \cdot 0$ & 31.9 & $23 \cdot 3$ & $19 \cdot 4$ \\
\hline \multicolumn{7}{|c|}{ Results for ${ }^{58} \mathrm{Fe}$} \\
\hline Mean & $23 \cdot 5$ & $21 \cdot 6$ & $23 \cdot 7$ & $23 \cdot 1$ & $22 \cdot 6$ & $22 \cdot 3$ \\
\hline SD & $7 \cdot 1$ & $6 \cdot 2$ & $6 \cdot 2$ & $6 \cdot 2$ & 5.9 & $6 \cdot 4$ \\
\hline Range & $13 \cdot 3-33 \cdot 6$ & $13 \cdot 8-30 \cdot 6$ & $13 \cdot 7-32 \cdot 2$ & $14 \cdot 9-32 \cdot 2$ & $14 \cdot 0-32 \cdot 0$ & $14 \cdot 0-32 \cdot 0$ \\
\hline Median & 23.4 & $21 \cdot 0$ & $25 \cdot 7$ & $24 \cdot 8$ & $23 \cdot 0$ & $23 \cdot 0$ \\
\hline \multicolumn{7}{|c|}{ Results for ${ }^{70} \mathrm{Zn}$} \\
\hline Mean & $40 \cdot 3$ & $38 \cdot 6$ & $38 \cdot 9$ & $39 \cdot 0$ & $39 \cdot 4$ & $39 \cdot 4$ \\
\hline SD & $5 \cdot 8$ & $9 \cdot 1$ & $7 \cdot 8$ & $7 \cdot 7$ & 7.5 & 7.5 \\
\hline Range & $31 \cdot 2-49 \cdot 6$ & $29 \cdot 9-56.5$ & $31 \cdot 6-53 \cdot 1$ & $31 \cdot 6-52.9$ & $31 \cdot 0-52.9$ & $31 \cdot 1-53 \cdot 0$ \\
\hline Median & $39 \cdot 3$ & $34 \cdot 2$ & $35 \cdot 2$ & $34 \cdot 7$ & $36 \cdot 6$ & $36 \cdot 8$ \\
\hline
\end{tabular}

The mean values for absorption obtained from the first two individual and the cumulative collection of the first two and three samples were significantly different from those of the cumulative collection of the first four and five samples: ${ }^{*} P<0.05$. The differences for ${ }^{58}$ Fe and ${ }^{70} \mathrm{Zn}$ were not significant for any comparison: $P>0.05$. $\dagger$ For details of subjects see Table 1; for details of procedures see p. 607.

¥ Farina meal: JD Cook, Kansas University Medical Center, Kansas City, KS, USA.

$\S$ Apparent absorption was calculated from the fractional recoveries of tracer and marker from the first and second individual and cumulative collection of $n$ sequential faecal samples. 
mean value of ratios derived from the first two individual samples and cumulative collection of the first two to four outputs clearly shows that endogenous excretion was not significant. As obtained for the ratios of recoveries, the mean values for absorption obtained from the first two individual stools and cumulative collections of the first two to five samples were not significantly different $(P>0.05)$ (Table 7). This indicates that the intestinal uptake of Fe and $\mathrm{Zn}$ could be determined from the recoveries of tracer and marker contents of the first or second individual stools or their composites.

\section{Discussion}

Investigations performed to confirm non-absorbability of rare earths demonstrate that they can be recovered quantitatively with total subject cooperation and attention to sample processing. Good agreement between recoveries of five selected rare earths confirms reproducibility of results when any member of this group of elements is used. When considering the use of light rare earths (e.g. La and Ce) as markers, baseline levels should be taken into account.

Quantitative recoveries have been obtained for the two rare earths ( $\mathrm{Sm}$ and $\mathrm{Yb}$ ) used to investigate reproducibility of recovery patterns of rare earths and unabsorbed isotopic tracers. Such recoveries suggest that rare earths could be used as markers in preference to polyethylene glycol, which is commonly used to confirm quantitative collections of faecal samples and for which losses due to hydrolysis, fermentation and absorption prevent reliable measurements (Allen et al. 1979). In the use of radio-opaque pellets as markers, their determination in stool samples requires X-ray of whole samples (Cummings \& Wiggins, 1976). Rare earth markers have an advantage over radio-opaque pellets in that they can be determined in fractions of homogenised samples.

The significant difference between the time of first appearance derived from the recoveries of Sm consumed with a solution and those of $\mathrm{Yb}$ consumed with a meal suggest that rare earths could be used to determine the intestinal transit time of various types of dietary intakes. Recovery profiles and intestinal kinetics of rare earths could also provide information on time-dependent biological variations in studies of intestinal physiology (Luckey, 1974, 1979). Measurement of mean transit times by the use of radio-opaque pellets is an accepted method for studies of excretion kinetics with markers (Hinton et al. 1969; Metcalf et al. 1987). Cummings \& Wiggins (1976) developed a method for measurement of mean transit time by analysis of single stool. The method offered a useful experimental approach for both epidemiological studies and as an outpatient procedure to reveal frequency of colon symptoms and irritable bowel syndrome (Talley et al. 1991). For such an approach, rare earths provide fourteen different elements possessing similar physicochemical characteristics, with advantages over radioopaque pellets in ease of determination and in having an homogeneous diffusion space in the intestine (unlike radioopaque pellets, where diffusion is determined by size and shape (Morgan, 1986)).
For ${ }^{57} \mathrm{Fe}$ tracer and Sm marker consumed with a drink, the recovery profiles were not identical. The mean values for intestinal uptakes of $\mathrm{Fe}$ obtained from the second individual and cumulative collection of the first two and three faecal samples provided after the consumption were significantly different $(P<0.05)$ from those obtained from composites of the first four and five samples. This was evidence for endogenous excretion of Fe initially taken up by the intestine. A similar effect has been observed in earlier studies using radioactive markers for $\mathrm{Cr}$ (Powell et al. 1970) and Ba (Jasani et al. 1971) where the marker and radioactive ${ }^{59} \mathrm{Fe}$ tracer were consumed in a drink. It was concluded that the intestinal uptake of Fe could be measured accurately only after ingestion of a test dose. In normal subjects when the tracer retained is measured $72 \mathrm{~h}$ after ingestion the values are lower than the initial measurement due to excretion of $\mathrm{Fe}$ initially retained (Marx, 1979). The results of this investigation agree with these conclusions. The mean of differences between the uptakes obtained from cumulative collection of the first two and five samples was $9.5 \%$, whereas the mean uptakes were $32.4 \%$ and $22.9 \%$ of the dose for the corresponding composites.

Unlike Fe consumed without food, the recovery profiles of ${ }^{58} \mathrm{Fe}$ and ${ }^{70} \mathrm{Zn}$ tracers and $\mathrm{Yb}$ marker consumed with food were closely parallel.

The uptake of Fe from the meal was consistent. The difference from the uptake of $\mathrm{Fe}$ consumed with the solution should be related to the composition of the mode of intake or chemical form of Fe. The effect of the mode of intake has been reported in previous studies where the absorption was determined by the aid of non-absorbable $\mathrm{BaSO}_{4}$ marker labelled with radioactive ${ }^{131} \mathrm{Ba}$ (Jasani et al. 1971; Jasani \& Fletcher, 1972). There was no temporary retention of $\mathrm{Fe}$ when it was given with a food, as $\mathrm{FeCl}_{3}$ or citrate labelled with radioactive ${ }^{59} \mathrm{Fe}$. The fraction of $\mathrm{Fe}$ temporarily retained when the retention of the marker was less than $1 \%$ was below the detection limit for nine subjects (Jasani et al. 1971). Jasani \& Fletcher (1972) showed that Fe absorption from a meal measured by monitoring composites of $3 \mathrm{~d}$ faecal collection was not significantly different from that determined by whole-body counting $10 \mathrm{~d}$ after administration. The results of this investigation confirm these conclusions. The mean of uptakes obtained from cumulative collection of the initial outputs was not significantly different from that obtained from complete collection $(P>0.05)$, where the mean uptakes were $23.7 \%$ and $22.3 \%$ of dose for the corresponding composites. The mean value for absorption from the Farina meal containing $3 \mathrm{mg} \mathrm{Fe}$ as $\mathrm{Fe} \mathrm{PO}_{4}$ labelled with radioactive ${ }^{59} \mathrm{Fe}$ tracer has been reported to be $1.75 \%$ for twelve subjects (Forbes et al. 1989), where the measurement of absorption was based on red blood cell incorporation. The mean value for intestinal uptakes of $\mathrm{Fe}^{3+}$ for the same meal obtained from this investigation was much higher than that measured by Forbes et al. (1989). This should be related to solubility of chemical form of $\mathrm{Fe}$ $\left(\mathrm{Fe} \mathrm{PO}_{4}\right.$ has a very low solubility compared with $\mathrm{FeCl}_{3}$ at $\mathrm{pH} 2$ ). It is worth noting that the mean value for absorption of Fe obtained from this study (23 (SD 6) \%) agrees with that obtained $(27 \cdot 2$ (SD 11) \%) by Björn-Rasmussen et al. 
(1972), where the dietary intake was wheat-based bread containing $0.3 \mathrm{mg} \mathrm{Fe}$ (labelled with radioactive ${ }^{59} \mathrm{Fe}$ as $\mathrm{FeCl}_{3}$ form) with tap water, and the absorption was determined by whole-body and blood counting.

The uptake of $\mathrm{Zn}$ from the meal was also consistent. Payton et al. (1982) determined the absorption of $\mathrm{Zn}$, administered as a solution, from the first three consecutive faecal samples. The authors used radioactive ${ }^{65} \mathrm{Zn}$ as tracer and ${ }^{51} \mathrm{Cr}$ as non-absorbable marker. Flanagan et al. (1985) used the same tracer and marker to investigate $\mathrm{Zn}$ uptake from a solution and a test meal. Results of both studies showed that intestinal uptake of $\mathrm{Zn}$ could reliably be determined by faecal monitoring and results were confirmed by whole-body counting. However, the associated exposure to radiation was a continuing limitation (Flanagan et al. (1985) estimated the radiation dose to be $500 \mu \mathrm{Sv}$ when $50 \%$ of ${ }^{65} \mathrm{Zn}$ was absorbed). The current investigation, involving no radioactivity, also showed that the intestinal excretion kinetics of $\mathrm{Yb}$ marker and the unabsorbed fraction of $\mathrm{Zn}$ tracer were identical, and the absorption of $\mathrm{Zn}$ from a meal could be determined accurately by analysis of the first two individual faecal samples or its composites. The questions related to the physiological process of intestinal uptake of $\mathrm{Zn}$ when determined with isotopic tracers are the amount of the endogenous contribution to total faecal output during the sample collection period, and the degree of uptake of the dietary mineral from the lumen, which is temporarily trapped in the mucosal cells and subsequently excreted in faeces. The endogenous contribution to total faecal output is considerable, ranging from $2.2 \mathrm{mg}$ to $5.4 \mathrm{mg}$, which is approximately equivalent to daily $\mathrm{Zn}$ absorption (Turnlund et al. 1986). The mean of absorption from the meal was approximately $40 \%$ which was equivalent to $1.2 \mathrm{mg}$ for this present investigation. If the same test meal was consumed three times over the course of a day, then the endogenous secretion would be $3.6 \mathrm{mg} / \mathrm{d}$. This is within the range given by Turnlund et al. (1986). A fraction of $\mathrm{Zn}$ taken up might be trapped in the intestinal mucosa, depending on regulatory factors of $\mathrm{Zn}$ absorption, such as vitamin $\mathrm{B}_{6}$, as suggested by Turnlund et al. (1991). Considering these factors, the effects of both endogenous contribution and temporary retention would be minimised by the rare earth marker approach, where the uptake of $\mathrm{Zn}$ is measured in the first two faecal samples or their composites.

The use of rare earth markers in studies of absorption using stable isotopic tracers should enable measurement of absorption with single or reduced faecal sampling, providing several advantages in practical applications of the absorption measurement studies with stable isotopic tracers. With the rare earth marker approach, confinement of subjects in a hospital or a nutrition unit would be short or unnecessary. The dose of tracer required for measurement of absorption would reduce proportionally to the reduction of the period of faecal sampling, so studies with stable isotopes would be more economical, thus enabling epidemiological investigations.

The rare earth marker approach has been validated for $\mathrm{Fe}$ and $\mathrm{Zn}$ using enriched stable isotopic tracers. Similar investigations could be applied to the other essential minerals as depending on its isotopic availability, and subject to similar verification of the comparable behaviour of marker and unabsorbed tracer. In this present investigation, the recoveries of markers with the first or second individual faecal samples were always higher than $10 \%$ of the dose administered and the least absorption determined in this investigation was $13 \%$ (5\% for only one subject for $\mathrm{Fe}$ consumed with the solution). The problems arising from the applicability of the rare earth marker approach for low Fe absorption have been discussed by Fairweather-Tait et al. (1997) when investigating the effect of Ca intake on absorption of $\mathrm{Fe}$; this was initiated as a result of this investigation.

\section{Acknowledgements}

We are very grateful to Professor P. J. Aggett for help and advice, to Dr G. McNeil for assistance in obtaining ethical approval and for processing of faecal samples in the first investigation, and to Professor M. E. J. Lean for assistance in obtaining ethical approval for the second investigation. The study was performed at the Scottish Universities Research and Reactor Centre, UK. Ulvi Ulusoy held a scholarship for a $\mathrm{PhD}$, supported by Cumhuriyet University, Turkey.

\section{References}

Allen LH, Raynolds WL \& Margen S (1979) Polyethylene glycol as a quantitative faecal marker in human nutrition experiments. American Journal of Clinical Nutrition 32, 427-440.

Björn-Rasmussen E, Hallberg L \& Walker RB (1972) Food iron absorption in man. I. Isotopic exchange between food iron and inorganic iron salt added to food: studies on maize, wheat, and eggs. American Journal of Clinical Nutrition 25, 317-323.

Charlton RW \& Bothwell TH (1983) Iron absorption. Annual Review of Medicine 34, 55-68.

Cook JD, Dassenko SA \& Lynch SR (1991) Assessment of the role of nonheme-iron availability in iron balance. American Journal of Clinical Nutrition 54, 717-722.

Crock JG \& Lichte FE (1982) Determination of rare earth elements in geological materials by inductively coupled argon plasma/atomic emission spectrometry. Analytical Chemistry 54, 1329-1332.

Cummings JH \& Wiggins HS (1976) Transit through the gut measured by analysis of a single stool. Gut 17, 219-223.

Esposito M, Collecchi P, Martines H, Aste H, Merlo F, Oddone M, Meloni S, Caramella Crespi V \& Genova N (1993) Plasma and tissue levels of some lanthanide elements in human colorectal lesions. Journal of Radioanalytical and Nuclear Chemistry 174, 23-28.

Fairweather-Tait SJ, Fox TE, Wharf SG, Eagles JI \& Kennedy H (1992) Zinc absorption in adult men from chicken sandwich made with white or wholemeal bread, measured by a doublelabel stable isotope technique. British Journal of Nutrition $\mathbf{6 7}$, 411-419.

Fairweather-Tait SJ, Jackson MJ, Fox TE, Wharf SG, Eagles J \& Croghan PC (1993) The measurement of exchangeable pools of zinc using the stable isotope ${ }^{70} \mathrm{Zn}$. British Journal of Nutrition 70, 221-234.

Fairweather-Tait SJ, Minihane AM, Eagles J, Owen L \& Helen MC (1997) Rare earth elements as nonabsorbable fecal markers in studies of iron absorption. American Journal of Clinical Nutrition 65, 970-976. 
Flanagan PR, Cluett J, Chamberline MJ \& Valberg LS (1985) Dual isotope method for determination of human zinc absorption: the use of a test meal of turkey meat. Journal of Nutrition 115, 111-122.

Forbes AL, Adams CE, Arnaud MJ, Chicester CO, Cook JD, Harrison BN, Hurrell RF, Kahn SG, Morris ER, Tanner JT \& Whittaker P (1989) Comparison of in vitro, animal, and clinical determinations of iron bioavailability: International Nutritional Anemia Consultative Group Task Force report on iron bioavailability. American Journal of Clinical Nutrition 49, 225-238.

Hasegawa Y, Sugawara T \& Choppin GR (1988) Thermodynamic parameters of complexation of lanthanoid(III) with ascorbic acid. Inorganic Chimica Acta 143, 277-280.

Hinton JM, Lennard-Jones JE \& Young AC (1969) A new method for studying gut transit times using radiopaque markers. Gut 10, 842-847.

Hutcheson DP, Venugopal B, Gray DH \& Luckey TD (1975) Studies of nutritional safety of some heavy metals in mice. Journal of Nutrition 105, 670-675.

Janghorbani M, Ting BTG \& Young VR (1980) Accurate analysis of stable isotopes ${ }^{68} \mathrm{Zn},{ }^{70} \mathrm{Zn}$ and ${ }^{58} \mathrm{Fe}$ in human feces with neutron activation analysis. Clinica Chimica Acta 108, 9-24.

Jasani BM \& Fletcher J (1972) Determination of iron absorption from measurement of radioactive iron and a non-absorbed radioactive marker in a single faecal sample. Scandinavian Journal of Haematology 9, 547-551.

Jasani BM, Tonge JL, Fletcher J \& Barnaby CF (1971) Measurement of the amount of ingested iron temporarily retained in the intestine. British Journal of Haematology 20, $131-137$

Johnson PE, Stuart MA, Hunt JR, Mullen L \& Starks L (1988) ${ }^{65}$ Copper absorption by women fed intrinsically and extrinsically labelled goose meat, goose liver, peanut butter and sunflower butter. Journal of Nutrition 118, 1522-1528.

Kotb AR \& Luckey TD (1972) Markers in nutrition. Nutrition Abstracts and Reviews 42, 813-844.

Kramsch DM, Aspen AJ \& Apstein CS (1980) Suppression of experimental atherosclerosis by the $\mathrm{Ca}^{++}$-antagonist lanthanum. Journal of Clinical Investigation 65, 967-981.

Laul JC \& Gosselin DC (1989) Radioanalytical methods for REE in geological and biological materials. In Lanthanide Probes in Life, Chemical and Earth Sciences - Theory and Practice, pp. 379-388 [CG Bunzli and GR Choppin, editors]. Amsterdam: Elsevier.

Laul JC, Lepel EA \& Smith MR (1988) Trace rare-earth element analysis of briny groundwaters. Journal of Radioanalytical and Nuclear Chemistry 123, 349-363.

Luckey TD (1974) Introduction: the villus in chemostat man. American Journal of Clinical Nutrition 27, 1266-1276.

Luckey TD (1979) Whither, intestinal microecology? American Journal of Clinical Nutrition 32, 109-112.

Luckey TD, Kotb A, Vogt JR \& Hutcheson DP (1975) Feasibility studies in rats fed heavy metals as multiple nutrient markers. Journal of Nutrition 105, 660-669.

Luckey TD, Venugopal B, Gray D \& Hutcheson D (1977) Lanthanide marker evidence for one and two physiologic compartments in the human alimentary tract. Nutrition Report International 16, 339-347.

Magnusson B, Bjorn-Rasmussen E, Hallberg L \& Rossander L (1981) Iron absorption in relation to iron status. Scandinavian Journal of Haematology 27, 201-208.

Marx JJM (1979) Mucosal uptake, mucosal transfer, and retention of iron, measured by whole body counting. Scandinavian Journal of Haematology 23, 293-302.

Mertz W (1987) Use and misuse of balance studies. Journal of Nutrition 117, 1811-1813.
Metcalf AM, Phillips SF, Zinsmeister AR, MacCarty RL, Beart RW \& Wolfe BG (1987) Simplified assessment of segmental colonic transit. Gastroenterology 92, 40-47.

Morgan JB (1986) Use of non-absorbable markers in studies of human nutrient absorption. Human Nutrition: Applied Nutrition 40A, 399-411.

O'Dell BL (1984) Bioavailability of trace elements. Nutrition Reviews 42, 301-308.

Payton KB, Flanagan PR, Stinson EA, Chodirker DP, Chamberline MJ \& Valberg LS (1982) Technique for determination of human zinc absorption from measurement of radioactivity in a fecal sample or the body. Gastroenterology 83, 1264-1270.

Pietra R, Sabbioni E, Ubertalli L, Orvini E, Vocatura G, Colombo F \& Zanoni M (1985) Trace elements in tissues of a worker affected by rare earths pneumoconiosis: a study carried out by neuron activation analysis. Journal of Radioanalytical and Nuclear Chemistry 92, 247-259.

Powell LW, Campbell CB \& Wilson E (1970) Intestinal mucosal uptake of iron and iron retention in idiopathic haemochromatosis as evidence for a mucosal abnormality. Gut 11, 727-731.

Solomons NW, Janghorbani M, Ting BTG, Steinke FH, Christensen M, Bijlani R, Istfan N \& Young VR (1982) Bioavailability of zinc from a diet based on isolated soy protein: application in young men of the stable isotope tracer ${ }^{70} \mathrm{Zn}$. Journal of Nutrition 112, 1809-1821.

Talley NJ, Zinsmeister AR, Van Dyke C \& Melton LJ III (1991) Epidemiology of colonic symptoms and irritable bowel syndrome. Gastroenterology 101, 927-934.

Turnlund JR, Durkin N, Costa F \& Margen S (1986) Stable isotope studies of zinc absorption and retention in young and elderly men. Journal of Nutrition 116, 1239-1247.

Turnlund JR, Keyes WR, Hudson CA, Betschart AA, Kretsch MJ \& Souberlich HE (1991) A stable-isotope study of zinc, copper, and iron absorption and retention by young women fed vitamin B-6-deficient diets. American Journal of Clinical Nutrition 54, 1059-1064.

Ulusoy U (1996) Determination of intestinal uptake of essential trace elements using stable isotopic tracers and rare earth markers. PhD Thesis, University of Glasgow.

Venugopal B \& Luckey TD (1975) Toxicology of non-radioactive heavy metals and their salts. Environmental Quality and Safety, Suppl. 1, pp. 75-80 [F Coulston and F Korte, editors]. London: Academic Press.

\section{Appendix}

Notation for derivation of the equations:

$\mathrm{E}_{\mathrm{f}}$, amount of element in faeces, including unabsorbed (enriched) isotopic tracer; $\mathrm{E}_{\mathrm{n}}$, amount of element in faeces which consists of the fraction of total element of natural composition; $\mathrm{I}_{\mathrm{f}}$, total isotopic content of faeces, including endogenous contribution of the enriching isotope and unabsorbed isotopic tracer; $I_{u}$, amount of unabsorbed isotopic tracer in faeces; $I_{e}$, endogenous contribution of the enriching isotope to the total isotopic contents of faeces; $R_{e}$, natural abundance of the enriching isotope; $M$, fractional recovery of marker; $I_{d}$, amount of enriched isotopic tracer provided with the dose; A, fractional absorption.

The total amount of the element of natural composition in a faecal sample:

$$
E_{n}=E_{f}-I_{u} .
$$


The amount of unabsorbed isotopic tracer in a faecal sample:

$$
\mathrm{I}_{\mathrm{u}}=\mathrm{I}_{\mathrm{f}}-\mathrm{I}_{\mathrm{e}} .
$$

The endogenous isotopic contribution of a faecal sample in natural composition:

$$
\mathrm{I}_{\mathrm{e}}=\mathrm{R}_{\mathrm{e}} \mathrm{E}_{\mathrm{n}} \text {. }
$$

If the faecal excretion kinetics of marker and unabsorbed tracer are identical, then for a recovery $M$ (as indicated by marker), at a fractional absorption of $\mathrm{A}, \mathrm{I}_{\mathrm{u}}$ is given by:

$$
\mathrm{I}_{\mathrm{u}}=\mathrm{M}(1-\mathrm{A}) \mathrm{I}_{\mathrm{d}},
$$

so A can be calculated from:

$$
\mathrm{A}=\frac{\mathrm{MI}_{\mathrm{d}}-\mathrm{I}_{\mathrm{u}}}{\mathrm{MI}_{\mathrm{d}}} .
$$

Combining equations $1 \mathrm{a}$ and 2 a gives:

$$
\mathrm{E}_{\mathrm{n}}=\mathrm{E}_{\mathrm{f}}-\mathrm{M}(1-\mathrm{A}) \mathrm{I}_{\mathrm{d}} \text {. }
$$

From equations $3 \mathrm{a}$ and $1 \mathrm{c}, \mathrm{I}_{\mathrm{e}}$ is given by:

$$
I_{e}=R_{e}\left(E_{f}-M(1-A) I_{d}\right) .
$$

Substituting $I_{e}$ from equation $3 b$ in equation $1 b$ gives:

$$
I_{u}=I_{f}-R_{e}\left(E_{f}-M(1-A) I_{d}\right) .
$$

Substituting $I_{u}$ from equation $3 c$ in equation $2 b$ gives:

$$
\mathrm{A}=\frac{\mathrm{MI}_{\mathrm{d}}-\left(\mathrm{I}_{\mathrm{f}}-\mathrm{R}_{\mathrm{e}}\left(\mathrm{E}_{\mathrm{f}}-\mathrm{M}(1-\mathrm{A}) \mathrm{I}_{\mathrm{d}}\right)\right)}{\mathrm{MI}_{\mathrm{d}}} .
$$

Rearranging equation 4 gives:

$$
A=\frac{M_{d}\left(1-R_{e}\right)+R_{e} E_{f}-I_{f}}{M_{d}\left(1-R_{e}\right)},
$$

which can be written as:

$$
A=1-\frac{I_{f}-R_{e} E_{f}}{M_{d}\left(1-R_{e}\right)} .
$$

In equation $5 b$, the term $\left(I_{f}-R_{e} E_{f}\right)$ is the amount of enriched isotopic tracer in the faecal sample which arises from feeding, the endogenous contribution being eliminated. The quantity of the enriched isotopic tracer provided with the dose, before isotopic dilution is $\left(I_{d}\left(1-R_{e}\right)\right)$, taking into account the contribution of the enriched source and the amount of natural tracer arising from its natural abundance. Since the isotopic content of dose and stool can be determined by NAA or MS, total element contents determined usually by atomic absorption spectrometry, and $\mathrm{M}$ by measuring their marker (rare earth) contents by NAA or MS, fractional absorption can be calculated by using equation $5 b$.

Equation $5 \mathrm{~b}$ can also be rearranged for calculation of the fractional absorption from the marker recoveries in individual faecal samples, $\mathrm{A}_{\mathrm{i}}$ :

$$
\mathrm{A}_{\mathrm{i}}=1-\frac{\mathrm{I}_{\mathrm{i}}}{\mathrm{M}_{\mathrm{i}}}
$$

where $I_{i}$ and $M_{i}$ are the fractional recovery of tracer given by $\mathrm{I}_{\mathrm{i}}=\left(\mathrm{I}_{\mathrm{f}}-\mathrm{E}_{\mathrm{f}} \mathrm{R}_{\mathrm{e}}\right) /\left(\mathrm{I}_{\mathrm{d}}\left(1-\mathrm{R}_{\mathrm{e}}\right)\right)$ and marker with individual faecal samples. The equation for $A_{i}$ can be used for calculation of the fractional absorption with any composites of individual samples by summation of the recoveries of the isotope and marker $\left(\mathrm{I}_{\mathrm{i}}\right.$ and $\left.\mathrm{M}_{\mathrm{i}}\right)$ with the corresponding individual outputs. 